\title{
"AFROUXARAM-SE OS JOELHOS E O CARO CORAÇÃO": UMA FÓRMULA HOMÉRICA E SEU EMPREGO POR CÁRITON ${ }^{1}$
}

\author{
Adriane da Silva Duarte* \\ Universidade de São Paulo
}

\begin{abstract}
Resumo. Sabe-se que Homero constitui a principal referência intertextual de Cáriton. Apesar do número crescente de estudos sobre essa relação, ainda resta muito a ser explorado. O propósito dessa comunicação é examinar o emprego de uma fórmula homérica

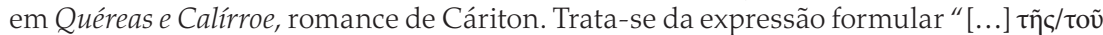

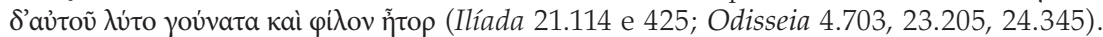
Essa fórmula, aplicada a Calírroe, Quéreas e Dioniso, repete-se três vezes ao longo do romance $(Q \mathcal{E} C 1.1 .14,3.6 .3,4.5 .9)$. Pretendo verificar se o autor faz um uso puramente genérico da citação, retendo apenas o seu sentido mais geral, visando apenas a emprestar o prestígio do poeta arcaico à sua obra, ou se há intenção de evocar um contexto específico do poema citado, de modo a criar uma expectativa quanto ao desenvolvimento da obra entre seus leitores. Resta ainda uma terceira possibilidade, a de seu uso estar vinculado a outro propósito, a saber, o de legitimar uma característica estilística do próprio autor, a de criar suas próprias fórmulas, através da emulação do antigo bardo. Palavras-chave. Intertextualidade; romance grego antigo; épica; Cáriton; Quéreas e Calírroe; Homero.
\end{abstract}

D.O.I. 10.11606/issn.2358-3150.v0i16p3-17

SABE-SE QUe Homero CONSTITUI A PRINCIPAL REFERÊNCIA INTERTEXTUAL de Cáriton. ${ }^{2}$ Apesar do número crescente de estudos sobre essa relação, ${ }^{3}$ ainda resta muito a ser explorado. Para além das aproximações de ordem temática, creio que uma das formas mais produtivas de investigá-la é aten-

* Profa. Dra. de Língua e Literatura Grega do Departamento de Letras Clássicas e Vernáculas da USP. Pesquisadora do CNPq.

* Artigo recebido em 19.ago.2014 e aceito para publicação em 5.out.2014.

${ }^{1}$ Uma versão resumida deste artigo foi apresentada durante o 14e Congrès International de la FIEC 2014, Bordeaux/França, apresentação que contou com auxílio da Fapesp.

2 Tilg 2010, 141: "One of the most conspicuous features of NAC [Narratives about Callirhoe] is the insertion of a large number of lines from the Iliad and the Odyssey. Chariton quotes Homer far more frequently than any other novelist does, about thirty to forty times depending of a definition of a quotation". Reardon 2003, 333: "The most frequent of all Chariton's literary references are to Homer".

${ }^{3}$ Cf. Müller 1976; Laplace 1980; Fusillo 1990; Manuwald 2000; Robiano 2000; Hirschberger 2001; Morales e Marisal 2003; Tilg 2010, 141-6. Anoto ainda o texto de M. Biraud ("L' hypotexte homérique et les rôles a amoureux de Callirhoé dans le roman de Chariton", in Sémiologie de l'amour dans les civilisation mediterranéennes, ed. A. Goursonnet, 21-27. Paris: Les Belles Lettres, 1985), ao qual infelizmente não tive acesso. 
tar para como os ecos dos poemas homéricos se materializam no texto de Cáriton através da incorporação de expressões recorrentes na épica. ${ }^{4}$ Mais do que catalogar tais expressões interessa estabelecer caso a caso o sentido que assumem nesse novo contexto, se é que, de fato, é possível determinar a existência de um nexo semântico necessário.

Na contramão dos estudos feitos, que pretendem oferecer uma visão geral da intertextualidade no romance de Cáriton, vou me dedicar a um exame de caso. ${ }^{5}$ Assim, proponho investigar nesse artigo o emprego de uma única fórmula homérica em Quéreas e Calírroe. Trata-se da expressão

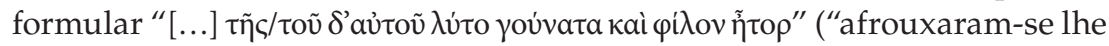
os joelhos e também o caro coração": em senso estrito em Ilíada 21.114 e 425; Odisseia 4.703, 23.205, 24.345). A escolha dessa fórmula deve-se ao fato de ter sido aplicada aos personagens principais, Calírroe, Quéreas e Dionísio, e de repetir-se três vezes ao longo do romance e em momentos diversos da narrativa $(Q \mathcal{E} C$ 1.1.14, 3.6.3, 4.5.9).

Para tal vou começar por analisar sua presença na Ilíada e na Odisseia e, em seguida, verificar seu emprego e função em Cáriton, pois é sabido que a fórmula, um elemento estruturador na poesia de caráter oral, não cumpre o mesmo papel no romance grego, em que a escrita é pressuposto e realidade. Pretendo verificar se o autor faz um uso puramente genérico da citação, retendo apenas o seu sentido mais geral, visando apenas a emprestar o prestígio do poeta arcaico à sua obra ou elevar o estilo da composição, ou se há intenção de evocar um contexto específico do poema citado, de modo a criar uma expectativa quanto aos rumos da narrativa entre os leitores capazes de identificá-la. ${ }^{6}$ Resta ainda uma terceira possibilidade, a de seu uso estar vinculado a outro propósito, a saber, o de legitimar uma característica estilística do próprio autor, a de criar suas próprias fórmulas, através da emulação do antigo bardo.

\footnotetext{
${ }^{4}$ Em Quéreas e Calírroe evidenciam-se as aproximações com a trama da Ilíada, já que a heroína, tal qual Helena, tem um marido grego, Quéreas, que vai à Jônia resgatá-la de um segundo casamento, com Dionísio. Assim, o triângulo formado por Quéreas, Calírroe e Dionísio e a oposição entre Grécia e Ásia remete ao paradigma de Menelau, Helena e Páris e às hostilidades entre gregos e troianos no poema de Homero. O romance ainda constrói paralelos com a Odisseia, em que o retorno dos protagonistas à Sicília natal e a fidelidade da heroína a seu primeiro marido os associam a Odisseu e Penélope. Cf. Laplace 1980; Morgan 2008; Whitmarsh 2011, 55.

${ }^{5}$ Para esses estudos de ordem geral Müller (1976) e Fusillo (1990) continuam referência.

${ }^{6}$ Discute-se muito sobre o público a quem os romances eram dirigidos, servindo o jogo intertextual, inclusive, como argumento em favor de um leitor culto contra a ideia de um público majoritariamente feminino ou de pouca instrução, que decorre do predomínio da temática amorosa. Noâmbito dessa análise remeto às reflexões de Robiano (2000, 528-9), que, através da análise das citações, defende que o romance exige um público erudito, apto a apreciar o jogo literário, e de Manuwald $(2000,119)$, que considera que Cáriton levou em conta tanto o leitor informado quanto o menos educado, uma vez que a não identificação das citações não prejudicaria a compreensão do enredo.
} 
Os autores que examinaram essa questão pouco se detiveram sobre essa fórmula, cujo emprego consideraram basicamente ornamental, preferindo centrar sua análise em outras passagens homéricas que, ao contrário dessa, aparecem apenas uma vez no texto de Cáriton e são maiores em extensão. ${ }^{7}$ E quando o fizeram, talvez por se prenderem a uma noção muito funcionalista da fórmula homérica, não buscaram explorar de forma exaustiva os vários contextos em que o verso aparece em Homero, o que julgo essencial para que se possa estabelecer o sentido que sua citação assume do romance de Cáriton. Não raro, a associam apenas a seu contexto iliádico, o do combate corpo a corpo, deixando de lado o seu emprego em situações diferentes na Odisseia. ${ }^{8}$ Passemos, portando, ao exame da fórmula em Homero.

\section{UMA FÓRMULA HOMÉRICA}

A expressão que vou examinar constitui uma unidade sintática, uma oração com sujeito e predicado, que em sentido estrito, ocupa quatro pés e meio finais do hexâmetro. Uma busca que leve em consideração seus ele-

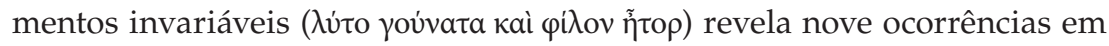
Homero, sendo duas na Ilíada e sete na Odisseia. O quadro a seguir sistematiza as ocorrências:

\begin{tabular}{|c|c|c|}
\hline & Ilíada 21.114 & 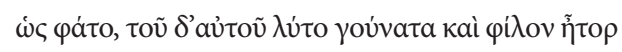 \\
\hline 2 & Ilíada 21.425 & 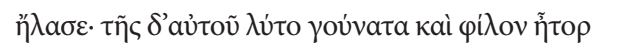 \\
\hline 3 & Odisseia 4.703 & 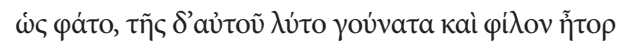 \\
\hline & Odisseia 5.297 & 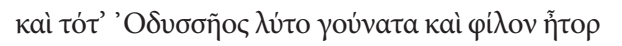 \\
\hline 5 & Odisseia 5.406 & 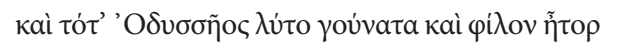 \\
\hline & Odisseia 22.68 & 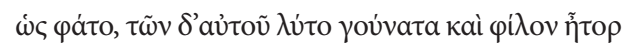 \\
\hline 7 & Odisseia 22.147 & 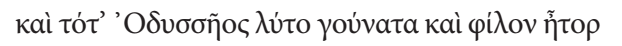 \\
\hline 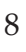 & Odisseia 23.205 & 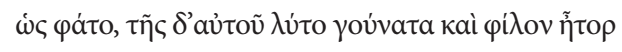 \\
\hline & Odisseia $24 \cdot 345$ & 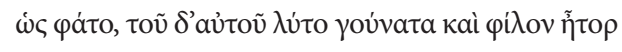 \\
\hline
\end{tabular}

${ }^{7}$ Fusillo 1990, 34: “Una prima e più scontata funzione è quella esornativa: impreziosire il raconto con brevi sintagmi omerici che per la loro formularità non attivano un rapporto fra i due conteste". Cf. também Manuwald 2000, 109 n. 39; Hirschberger 2001, 159.

${ }^{8}$ Cf. Fusillo 1990, 34: "Trata del episodio de Licaone nell' Iliade, priva quindi di contenuto erotico [...]", ou seja Il. 21.114. Também Morales e Marisal 2003, 294 n. 9. Uma exceção é Müller (1976, 129 n. 73), que se refere especialmente aos empregos da fórmula na Odisseia, procurando estabelecer relações contextuais, mas ainda assim no limite de uma nota de rodapé. Cf. Manuwald 2000, 108 n. 39. 
Na sua parte fixa temos o sintagma formado por sujeito composto

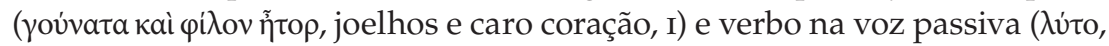
afrouxaram-se). Como elementos variáveis, há a indicação de quem é afetado pela ação, indicado por uma forma possessiva, artigo/pronome ou

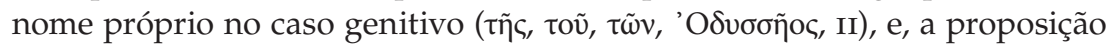
inicial que corresponde ao primeiro pé do hexâmetro (III).

Essa posição é ocupada cinco vezes pela oração ( $\dot{\omega} \varsigma$ páto, assim fa-

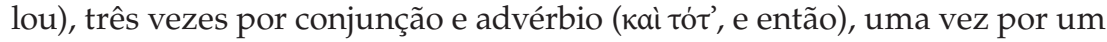

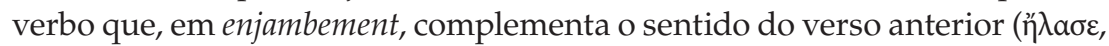
golpeou). Considerando que o núcleo é estável e o que varia não modifica drasticamente o sentido geral do conjunto, pode-se considerar que esse é um verso formular. Para maior clareza, veja-se o quadro abaixo:

\begin{tabular}{|c|c|c|c|c|}
\hline & & & 11 & III \\
\hline & Ilíada 21.114 & , & oṽ & 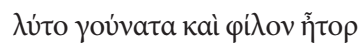 \\
\hline & Ilíada 21.425 & 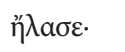 & $\tau \tilde{\eta} \varsigma \delta^{\prime}$ aủtoṽ & 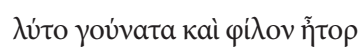 \\
\hline & Odisseia 4.703 & $\varsigma$ ५ & $\tau \tilde{\eta} \varsigma \delta^{\prime}$ & $\tilde{\hat{\eta} \tau} \tau \rho \rho$ \\
\hline & Odisseia 5.297 & кaì тót' & 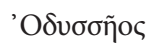 & 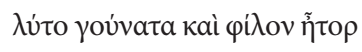 \\
\hline & Odisseia 5.406 & kaì тó ‘' & 'O $\delta$ vo & ก̃ $\tilde{\tau}$ \\
\hline & Odisseia 22.68 & 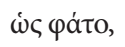 & $\tau \tilde{\omega} \nu \delta^{\prime} \alpha \dot{\tau} \tau o \tilde{v}$ & 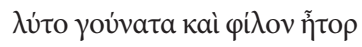 \\
\hline & Odisseia 22.147 & kaì тót' & 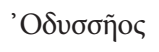 & $\lambda \circ \nu$ ทेंo $\rho$ \\
\hline & Odisseia 23.205 & 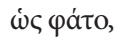 & $\tau \tilde{\eta} \varsigma \delta^{\prime}$ aủंoṽ & 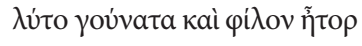 \\
\hline & Odisseia 24.345 & 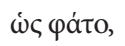 & 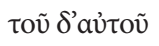 & 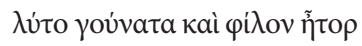 \\
\hline
\end{tabular}

O sentido geral da fórmula não coloca dificuldades. Trata-se da descrição da reação de impotência de quem é submetido a um golpe físico (2) ou, na maioria das vezes, moral $(1,3,4,5,6,7,8,9)$. Como consequência produz-se um colapso a uma só vez emocional e físico, que pode culminar no desfalecimento, evocando uma sensação de morte. ${ }^{9}$ Como visto, em cinco ocorrências a reação se dá em resposta a algo que foi dito $(1,3,6,8,9)$; em três, a algo que foi visto $(4,5,7)$ e em uma, a um impacto físico (2).

Resta examinar quem experimenta essa reação extrema e em que

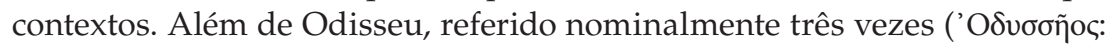

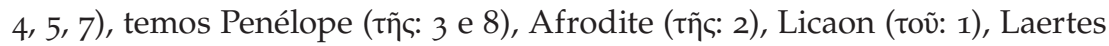

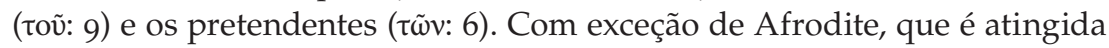

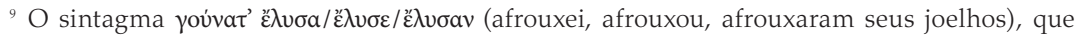
traz o verbo na voz ativa, com diversas ocorrências na Ilíada e na Odisseia, é empregado como eufemismo para matar.
} 
por Atena numa disputa entre os deuses e cai por terra (2), pode-se dividir as outras ocorrências em dois casos:

(a) situação em que há risco de vida, quer a própria quer a de um parente (Licaon teme diante de Aquiles: 1; Penélope teme por Telêmaco: 3; Odisseu teme morrer no mar ou nas mãos dos pretendentes: 4, 5, 7; os pretendentes temem diante de Odisseu: 6);

(b) situação em que se experimenta uma grande alegria (Penélope e Laertes reconhecem Odisseu em seu retorno, 8 e 9). Ou seja, tanto o medo quando a alegria desmedidos são fatores de estresse físico e emocional.

Por fim, vale ainda mencionar uma variação da expressão. Na Odisseia (18.212) tem-se uma versão reduzida do elemento fixo, agora na metade inicial do hexâmetro:

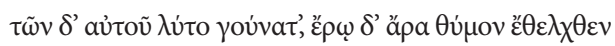

afrouxaram-se lhes os joelhos e seu ânimo sucumbiu ao encanto de eros.

A referência aqui é à reação dos pretendentes diante de Penélope, que com o concurso de Atena, os seduz para angariar tesouros para a casa. Embora não corresponda exatamente à citação feita por Cáriton, a proximidade de eros e do contexto amoroso pode ser significativa para a análise da fórmula em Quéreas e Calírroe.

\section{UMA FÓRMULA HOMÉRICA EM CÁRITON}

Em Cáriton, a fórmula ocorre três vezes, sempre em um recorte muito

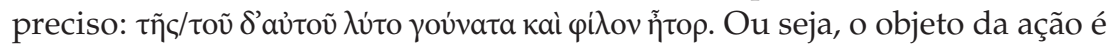
um "ele" ou "ela" (na verdade, um "dele" ou "dela"). Em cada uma dessas ocorrências (1.1.14, 3.6.3, 4.5.9), a frase se aplica a um dos personagens que formam o triângulo amoroso do romance: Calírroe (1.1.14), Cáriton (3.6.3) e Dionísio (4.5.9), e na ordem estrita em que eles entram na trama. Em todos os casos, a citação não está identificada no texto, mesclando-se à voz do narrador, que é a forma predominante de citar por Cáriton, não sendo atribuída às personagens, o que é significativo para a leitura que será proposta. ${ }^{10}$

${ }^{10}$ Tilg 2011, 141: "In NAC (...) quotations are usually not even announced or otherwise introduced but inserted as parts of Chariton's own narrative". Das cerca de quarenta citações de Homero no romance, apenas quatro fazem referência ao seu autor. Para análise dessas ocorrências, Tilg 2011, 144-6. 
Num primeiro momento, o uso reiterado da fórmula para caracterizar as três personagens principais revela a intenção de atrelá-las a um mesmo destino. Qual seja, a pista pode estar no contexto homérico das citações. Lidas contra o pano de fundo dos poemas homéricos, o relacionamento entre a heroína e seus dois maridos remete à situação de Helena, mulher a uma só vez do grego Menelau e do troiano Páris. De fato, o paralelismo dessa relação já foi bastante explorado, inclusive por Cáriton, que se refere constantemente a esse modelo. ${ }^{11}$

Mas essa fórmula em particular, como visto, não se aplica a nem a Helena, nem a Menelau, nem a Páris. Ela é muito mais frequente na Odisseia do que na Ilíada e está ligada a um contexto de pathos exacerbado. Os três personagens do romance a que ela é aplicada têm em comum uma grande suscetibilidade às emoções, condição a que estão submetidos por influência da paixão, ou, se preferir, de Eros. Esse dado, como visto, encontra-se em Homero, já que descreve um colapso dos sentidos que é antes emocional do que físico - muito embora na épica só na variante encontrada na Odisseia xviII é Eros está na origem do abalo.

O elemento patético é muito pronunciado em Quéreas e Calírroe. ${ }^{12}$ Os principais personagens estão sempre às voltas com um turbilhão de emoções que os levam a um constante esgotamento que beira ao colapso físico e à morte. Imagens que sugerem a morte iminente e ameaças de suicídio são frequentes ao longo do romance..$^{13}$

De forma geral, os estudos dedicados à questão consideram a citação em função de um dos motivos seguintes: elevação do estilo (poesia = nobre, prosa = pedestre), legitimação de um gênero ainda não codificado (através da associação com um gênero tradicional e bem aceito), caracterização dos personagens (construídos a partir de paradigmas bem estabelecidos). Não menos significativo é o desejo de estabelecer um jogo erudito com os leitores centrado no reconhecimento das passagens que via de regra em Cáriton não são identificadas textualmente. Note-se que há no romance uma fusão entre os versos de Homero e a voz do narrador, que se misturam sem que o leitor seja avisado disso (Tilg 2010, 141-2). Esse artifício retórico possibilita

\footnotetext{
${ }^{11}$ Cf. Laplace 1980; Hirschberger 2001. Cáriton, Quéreas \& Calírroe 2.6.1, 5.2.8.

${ }_{12}$ Hirschberger 2001, 182: "Charitons vorliebe für Pathos und Paradoxon entspricht Strömmungen in der hellenistischen Literatur (...). Auch die intertextuallen Bezüge in seinem Roman können dem Ausdruck von Pathos und Paradoxon dienen: So steigert Chariton beispielsweise in Ohnmachtsszenen das Pathos durch die Verwendung von Homerversen."

${ }^{13}$ Quéreas tenta o suicídio diversas vezes (p. ex. 1.5.2, 1.6.1, 3.1.1, 3.5.6, 5.10.6), Dionísio também concebe essa possibilidade quando não consegue conquistar o amor de Calírroe (3.1.1). Há ainda as mortes aparentes (Scheintod) de Calírroe e Quéreas, que são objeto de luto (1.5.1, 1.6, 4.I.1).
} 
a identificação e empatia do leitor, capaz de decifrar as passagens, com o autor, visando a boa aceitação da obra. ${ }^{14}$

Embora admita que, em sentido geral, Cáriton tenha citado a fórmula em questão por uma dessas duas razões, a saber, vincular suas personagens à tradição da épica homérica e enfatizar o componente patético de sua narrativa, parto do princípio de que, em Quéreas e Calírroe, o estabelecimento do contexto da citação não é irrelevante, ao contrário, importa para a uma interpretação plena. Passo, então, ao exame de cada uma das citações. Justamente por acreditar que Cáriton cita Homero com conhecimento de causa, tendo em mente um determinado passo dos poemas épicos, vou restringir minha análise às ocorrências que há coincidência absoluta com as passagens referidas. Com isso, elimino as referências que correspondem às entradas de número 4 a 7 no quadro da página 6.

\section{CALÍRROE: AFRODITE E PENÉLOPE}

O primeiro registro da fórmula em Cáriton ocorre no início do livro I, logo no primeiro capítulo. Cabe dizer que é também a primeira citação de Homero no romance. O capítulo um é muito movimentado: o par protagonista é apresentado ao leitor, seu encontro é providenciado por Eros, a paixão fulminante nasce, os empecilhos para união são superados, o casamento sacramentado. Enfim, o primeiro capítulo traz em si argumento para todo um romance cujo ápice fosse o casamento e não, como é caso aqui, tivesse por objetivo narrar as vicissitudes que o casal deve enfrentar após seu enlace. Ao seu final, quando a cidade inteira já comemora o assentimento dado pelo pai da noiva à sua união com Quéreas, Calírroe ainda jaz na ignorância. Recolhida a seus aposentos, ela está entregue à dor do amor irrealizado, quando recebe a notícia da sua boda imediata. A reação é assim descrita pelo narrador:

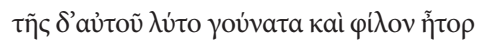

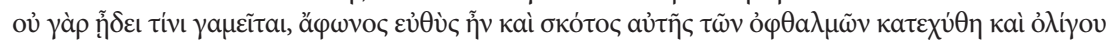

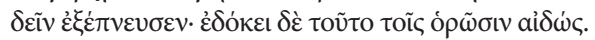

Afrouxaram-se lhe os joelhos e também o caro coração,

pois não sabia com quem se casaria. Ficou de imediato sem voz, e a escuridão cobriu seus olhos e por pouco não expirou. Aos que a viam, isso parecia recato. ${ }^{15}$

${ }^{14}$ Manuwald 2000, 101, 119; Robiano 2000, 128-9; Hirschberger 2001, 183.

${ }_{15}$ As traduções são de minha autoria. Para a citação do grego, sigo a edição de Reardon (Chariton 2004), que optou por destacar as citações homéricas do corpo do texto, o que não acontece nos manuscritos antigos em que há um contínuo indistinto - vale lembrar ainda que as aspas 
Noto aqui a associação da fórmula estudada com uma variante de

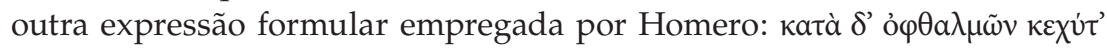
ảxגúc ("uma névoa cobriu-lhe os olhos", Il. 5.696, também com variações em Il. 20.321 e 421, Od. 22.88), em contexto de morte em batalha. ${ }^{16}$ Reforça-se aqui a ideia de morte, ainda que figurada.

Em Homero, há três ocorrências em que há total coincidência com a citação feita por Cáriton (cf. quadro, números 2, 3 e 8). As referências são a Afrodite (2) e Penélope (3 e 8). Não há como ignorar que ambas, deusa e mortal, contribuem para a constituição do caráter da heroína.

A ligação entre Calírroe e Afrodite, a quem é comparada inúmeras vezes ao longo da história, é evidente e de máxima relevância para a caracterização da heroína. ${ }^{17}$ Embora seja importante estabelecer para o leitor essa relação entre a heroína e a deusa desde cedo, o contexto do verso homérico é muito diverso desse do romance, já que a deusa é abatida por Atena no campo de batalha (Ilíada 21.114). Ora, Afrodite é a divindade mais poderosa de Quéreas e Calírroe e uma passagem que remetesse à sua humilhação justo no momento em que se celebra seu triunfo não parece muito adequada afinal é o casamento arranjado por Eros, seu filho, e por ela ratificado, que se está prestes a anunciar.

No entanto, a associação da deusa com a heroína é sempre bem-vinda e no contexto específico faz sentido. A deusa do amor abatida pela deusa da razão traduziria a decepção de Calírroe ao crer frustrada a prece que fizera no templo, a de ter Quéreas por marido - lembre-se que, no momento, ela ignora a identidade do noivo escolhido por seu pai, tendo todos os motivos para crer que não seria um desafeto da família, como Quéreas. Assim, a queda da deusa descreve bem a situação da heroína, que também ela crê ter levado uma rasteira da Fortuna.

No plano geral do romance, se Calírroe é uma versão de Helena, favorita de Afrodite, ela também evoca Penélope, a heroína da Odisseia. ${ }^{18}$ No início do romance, a corte que Calírroe recebe de inúmeros pretendentes

ainda não tinham sido inventadas. Claro que o ritmo do verso em meio a prosa denunciaria aos ouvidos habituados a citação.

${ }^{16}$ Cáriton substitui ảx入úc (névoa) por okótoc (escuridão), mas emprega o termo em 3.1.3. Mais

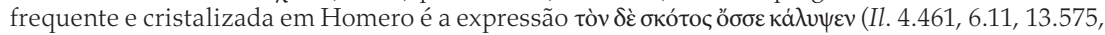
$14.519,16.316$ e $325,20.393,20.471,21.471)$. O sentido é o mesmo, o que pode levar a crer que Cáriton estivesse parafraseando Homero aqui ou tenha fundido as duas fórmulas com intuito de criar uma nova. Essas variações são estudadas por Manuwald (2000). Cf. também Tilg 2011, 144: "We may conclude that Chariton thinks of NAC to some extent, at least from a metaliterary point of view, as a recreation of Homeric epic and that he imagines himself a Homer in prose".

${ }^{17}$ P. ex. Quéreas \& Calírroe 1.12, 1.14.1, 2.2.6, 2.3.6, 3.2.14, 3.2.17, 3.9.1 etc. Também são frequentes as preces da heroína à deusa. Cf. Laplace 1980, 121-4.

${ }^{18}$ Um dos pontos mais significativos é o emprego por Cáriton (8.1.16) de um verso de Homero que marca o reencontro amoroso entre Odisseu e Penélope (Od. 23.296) para celebrar a reunião 
jovens e orgulhosos é o vínculo mais evidente entre elas, mas ao longo do romance outros aparecerão, sobretudo a fidelidade a Quéreas que nem o segundo casamento, apresentado como um recurso extremo para preservar a vida do filho que esperava dele, compromete (cf. 3.11).

A fórmula citada, quando aplicada a Penélope, evoca dois contextos. No primeiro (Odisseia 4.703) a rainha é informada de que os pretendentes armaram uma emboscada contra Telêmaco e sente-se fraquejar. Tanto tramoias de pretendentes quanto a integridade do filho estão no horizonte do romance, de modo permitir pensar que a fórmula evocasse na mente do leitor familiarizado com Homero essas situações inquietantes, gerando assim expectativa quando ao desenrolar da trama.

De fato, as expectativas assim geradas não tardam a se confirmarem. O início do segundo capítulo (1.2) é marcado pelo inconformismo dos jovens que cortejavam Calírroe e foram preteridos por Quéreas. Ofendidos com o casamento da moça, tramam para desfazê-lo incitando os ciúmes do rapaz. A farsa que armam vai resultar na agressão da heroína pelo marido e sua suposta morte, que sela a separação do casal protagonista. No livro II (2.8), Calírroe, agora escrava na casa de Dionísio, descobre que espera um filho de Quéreas e considera abortar a criança, o que é motivo de grande angústia para ela.

Müller (1976, 129, n. 73) indica brevemente a semelhança entre as duas passagens, em que Calírroe está para Penélope; a Ama que traz a notícia do casamento, para o arauto que revela a maquinação dos pretendentes; a notícia do casamento, à da emboscada, sendo que ambas indicam a perda definitiva de um ser amado (Quéreas para Calírroe; Telêmaco para Penélope).

A segunda ocorrência da fórmula associada a Penélope (Odisseia 23.205) dá-se no contexto do reconhecimento de Odisseu. Como é bem conhecido, Penélope demonstra ceticismo quando Euricleia anuncia o retorno do herói e, reticente, resolve testá-lo, o que resulta numa das cenas de reconhecimento mais longas do poema. Uma vez comprovada sua identidade, a esposa finalmente sucumbe à emoção, relaxando joelhos e coração.

Em Cáriton, tal como a heroína de Homero, Calírroe está em seu quarto quando a ama entra para anunciar a grande novidade. Como Penélope, a moça não acredita que o noivo que lhe aguarda seja o seu amado Quéreas e terá de ver para crer. A diferença está no fato de que o uso da fórmula aqui antecede o reconhecimento. A emoção da heroína não está vinculada ao reconhecimento, mas à presunção de que será dada em ca-

entre Quéreas e Calírroe, equiparados assim ao par da Odisseia. Cf. também Hirschberger 2001, 167-8; Morgan 2008, 220. 
samento a alguém que não Quéreas. No entanto, se o leitor, que conhece a identidade do noivo, associar a fórmula ao contexto do reconhecimento na Odisseia, perceberá que o narrador prepara na sequência a introdução de uma cena de anagnorisis. Eis o desenrolar da narrativa (1.1.14):

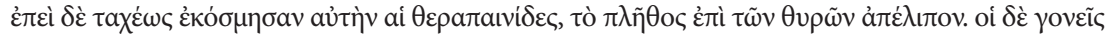

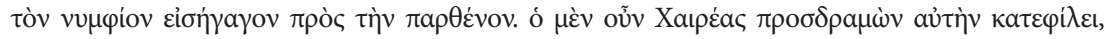

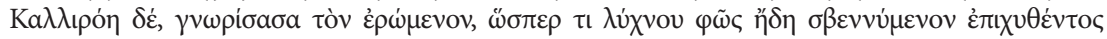

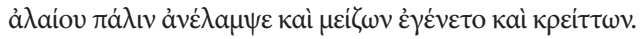

Tão logo as criadas a adornaram, a multidão afastou-se das portas, enquanto o noivo era conduzido por seus pais até a moça. Quéreas aproximou-se e a beijou. Ao reconhecer o homem amado, Calírroe brilhou novamente, como o lume quase extinto de uma lamparina quando o óleo é reposto, e ficou maior e mais forte. ${ }^{19}$

Pode-se concluir que cada uma das ocorrências da fórmula em Homero tem algo a dizer sobre a heroína de Cáriton e não seria exagero sugerir que o romancista tinha em vista as três passagens. No entanto, me parece que a analogia é maior no que concerne à última, dada a proximidade dos contextos. É ainda mais significativa na medida em que o reconhecimento é um motivo estrutural do romance de Cáriton e fundamental para o desenlace da trama.

\section{QUÉREAS: LAERTES, IMPOTENTE ANAGNÓRISIS}

A fórmula é citada uma segunda vez no decorrer do livro III, quando, após a descoberta que Calírroe estava viva e fora vendida por piratas a um rico senhor na Jônia, Quéreas parte em missão de resgate. Ao chegar à Jônia, depara-se com um templo de Afrodite, a quem vai render culto e pedir ajuda. Finda a prece, ao levantar a cabeça, defronta-se com uma estátua da esposa (3.6.3):

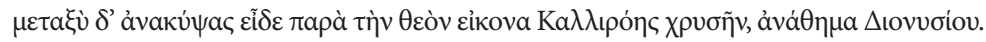

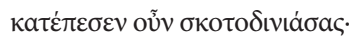

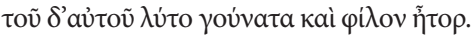

Enquanto isso ergueu-se e viu ao lado da deusa uma estátua de ouro de Calírroe, oferenda de Dionísio.

Afrouxaram-se lhe os joelhos e também o caro coração.

Então, a vista escureceu e tomado de vertigem, caiu.

\footnotetext{
${ }^{19}$ Note-se aqui o símile que Cáriton cria, mimetizando o estilo homérico. Cf. acima, n. 16.
} 
Por se tratar de personagem masculino, a fórmula traz agora o artigo toṽ, coincidindo, nesse caso, com uma passagem da Ilíada (21.114) e outra da Odisseia (24.345). Embora a Ilíada seja um intertexto importante para a caracterização de Quéreas, especialmente no que respeita sua aproximação com Aquiles, ${ }^{20}$ a passagem da Odisseia parece mais promissora para esclarecer o contexto buscado no romance. Como já observou Müller (1976, 129, n. 73), a situação em que Quéreas se encontra também remete a cena de um reconhecimento, ainda que indireto. Ao atentar para a estátua, nela reconhece Calírroe, ou melhor, reconhece que Calírroe foi o seu modelo. Tomado por violenta emoção, desfalece de fato, como revela a sequência do texto.

Na Ilíada (21.114), o verso é empregado ao final do encontro fatal entre o troiano Licaon e Aquiles, quando aquele vê negada a súplica que fez ao grego para que lhe poupe a vida. Diante da iminência da morte, deixa-se abater. Como, no momento em que percebe a imagem da esposa, Quéreas ainda não sabe o que se passou com ela, qual o seu paradeiro, se está viva ou morta, a reação é fruto de estupor e, num primeiro momento, até mesmo de alegria. Não parece que haja vínculo com a situação de Licaon.

Na Odisseia (24.345), a fórmula é usada para descrever a reação de Laertes quando reconhece que o estrangeiro com quem conversava era de fato seu filho Odisseu. Trata-se do mesmo contexto de uma das ocorrências que envolvem Penélope (Od. 23.205). O reconhecimento entre Quéreas e Calírroe, que só virá a acontecer no livro viII, ${ }^{21}$ marca o clímax do romance, pois é pressuposto para o final feliz que caracteriza o gênero. Não é despropositado pensar, então, que o uso da fórmula homérica, remeta a esse contexto, antecipando de certa forma o encontro do casal, que por distante deve ser insinuado ao leitor. Então a aproximação não se faria entre Quéreas e Laertes, desiguais na idade e no ethos, mas através da circunstância que os une, o reconhecimento inesperado do amado e também, em certo grau, a impotência que sentem para momentos antes da identificação - Quéreas vinha de confessar a dificuldade de buscar Calírroe por toda a Jônia sem sequer mesmo ter garantias de que estivesse viva (3.6).

${ }^{20}$ Cáriton compara Quéreas a Aquiles desde o livro i (1.1.3, 1.5.2). Cf. Morales e Marisal (1996), para as citações de Homero em que Quéreas é assimilado a Aquiles. Também Morgan 2008, 219-20.

${ }^{21}$ Embora marido e mulher tenham oportunidade de se avistar antes disso, durante o julgamento na Babilônia (5.8), não trocam palavra e permanecem separados. O reconhecimento que sela a reunião do casal ocorre portanto apenas em 8.1.8: "Enquanto ele falava, Calírroe reconheceu ( $\gamma \nu \omega \rho i \sigma \alpha \sigma \alpha)$ sua voz e desvelou-se. E, ao mesmo tempo, ambos exclamaram: Quéreas! Calírroe!". 


\section{DIONÍSIO: LICAON, UMA VÍTIMA DE AQUILES}

A terceira e última ocorrência da fórmula aplica-se a Dionísio (4.5.9). Durante um banquete em sua casa, recebe cartas enviadas por Mitridates, o persa de quem Quéreas era escravo. Em meio a elas há uma mensagem endereçada a Calírroe, que lida inadvertidamente, causa um abalo tão profundo que resulta num desmaio:

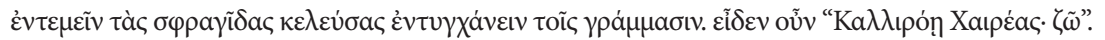

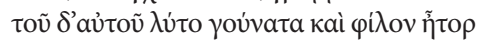

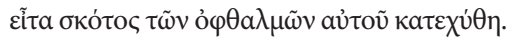

[Dionísio] mandou romper os lacres e passou à leitura de seu conteúdo. Bateu os olhos no seguinte: "Para Calírroe de Quéreas. Estou vivo."

Afrouxaram-se the os joelhos e também o caro coração,

e então a escuridão cobriu seus olhos.

As referências em Homero são as mesmas mencionadas para a passagem protagonizada por Quéreas. No caso de Dionísio, sua situação parece estar mais próxima da de Licaon (Ilíada 21.114) do que a de Laertes (Odisseia 24.345), já que saber que Quéreas estava vivo e procurava recuperar Calírroe, representava uma ameaça a sua vida. Anteriormente, em diversas ocasiões, Dionísio deixara claro que lhe era impossível continuar a viver uma vez privado de Calírroe, chegando mesmo a planejar seu suicídio diante da recusa da moça à sua corte (3.1). Assim, a carta interceptada equivale para ele a uma sentença de morte. Também é significativo notar que Licaon recebe o golpe final de um Aquiles enfurecido pela morte de seu amado Pátroclo. Dado que o narrador do romance equipara Quéreas e Aquiles e que através das citações da Ilíada o relacionamento entre herói e heroína será associado ao que mantém Pátroclo e Aquiles, é possível sugerir que Cáriton quisesse insinuar a seus leitores que Dionísio pagará com a vida a ofensa feita a seu herói vingador. ${ }^{22}$

Já o contexto odisseico não parece se adaptar a ele, a não ser pelo viés mais geral, o do baque emocional, pois qualquer alusão a reconhecimento é estranha aqui. No entanto, vale notar que Müller (1976, 129, n. 73) sugere que a citação remeta ao canto xxII da Odisseia (cf. quadro, número 6), em que os pretendentes temem diante do regresso de Odisseu. Deve-se admitir que aqui a analogia também é possível, devendo ter ocorrido aos leitores

${ }^{22}$ Tal ameaça ficará no horizonte apenas, não se cumprindo no âmbito da narrativa. Calírroe retorna a Sicília com Quéreas deixando a Dionísio uma carta em que recomenda os cuidados que deve ter com o filho, que ele assume ser seu. Como em outras situações Dionísio cogita a morte se fosse privado de Calírroe, essa não é uma hipótese de todo absurda. 
contemporâneos do romance, embora não haja coincidência absoluta entre as passagens citadas.

\section{CONCLUSÃO}

Após concluída a análise das passagens em que a fórmula homérica é citada, considero que seu emprego cumpre diversas funções no interior do romance.

No que concerne ao estilo, o recurso a uma fórmula conhecida tem, sem dúvida, uma intenção ornamental, na medida em que eleva a linguagem ao nível dos paradigmáticos poemas homéricos. O narrador não só cita Homero como o parafraseia, comparando-se ao poeta, uma maneira de demonstrar que a prosa, por pedestre que seja, pode almejar uma elocução alta.

No âmbito semântico, a fórmula põe em destaque a sensação extremada de falência emocional e física, característica da exacerbação dos elementos patéticos predominante na estética do romance erótico. Tem a vantagem de, ao ser empregada para caracterizar a reação dos principais personagens do romance, vincular seus destinos, dando relevo ao triângulo amoroso de que são protagonistas. Essa associação evoca obviamente o triângulo que o próprio Homero traça na Ilíada, entre Helena, Menelau e Páris, que serve de pano de fundo mítico à narrativa, muito embora a fórmula citada não se aplique originalmente a nenhum deles.

Até aqui, os efeitos buscados ocorrem mesmo que o verso citado não seja claramente identificado pelos leitores. Basta para tal a impressão de que o autor escreve à maneira de Homero ou a percepção de que a citação se repete para Calírroe, Quéreas e Dionísio. Caso o leitor reconheça a citação e sua fonte, parece natural que tentasse estabelecer aproximações com os contextos específicos dos poemas. Espero ter demonstrado que essa leitura não só é possível como enriquece o texto de chegada, tornando mais complexas as reações e as relações entre os personagens. Se fui persuasiva ao associar as cenas em que participam Calírroe e Quéreas a reconhecimentos (Od. 23.205 e 24.345) e a de Dionísio a morte (Il. 21.114), tais referências antecipariam de certa forma o destino das personagens: o final feliz para os protagonistas e o trágico para Dionísio.

Por fim, no âmbito da narrativa, o uso da fórmula, assim como as demais citações que abundam no romance, contribuem para caracterizar o narrador como um erudito, conhecedor de Homero, característica que ele deve partilhar com seu leitor, ao menos parcialmente. Duas consequências decorrem disso. 
Por um lado, reforça-se vínculo desse novo gênero que é o romance (do qual Cáriton conta entre os primeiros expoentes) com a épica e, portanto, com toda a tradição da poesia grega. Assim, muito embora as citações raramente tenham função argumentativa em Cáriton, pode-se dizer que o conjunto das citações inseridas no texto assume essa característica, ajudando a consolidar a autoridade do narrador e, consequentemente do seu relato, que buscam se valorizar aos olhos dos leitores. ${ }^{23} \mathrm{Ou}$ seja, se a fórmula é empregada também para aprimorar a caracterização dos personagens, tem o mesmo efeito quando é o ethos do narrador que está em questão.

Por outro lado, a citação estabelece a intertextualidade como um jogo entre autor e leitor. Nesse caso, importa menos a erudição do autor do que a do leitor, que encontraria prazer em reconhecer e precisar cada citação. Assim como o pathos exacerbado, os jogos eruditos são herança de uma estética helenística que sustenta a literatura que se faz no período imperial.

Espero ter demonstrado, portanto, que o emprego da fórmula homérica por Cáriton está longe de ser um mero recurso estilístico, tendo em vista a linguagem ornamentada. ${ }^{24}$

\section{REFERÊNCIAS}

Chariton. 1979-1989. Le roman de Chairéas et Callirhoé. Édité par G. Molinié. Paris: Les Belles Lettres.

Chariton. 1995. Callirhoe. Edited by G. P. Goold. Cambridge-Mass: Cambridge University Press.

Chariton. 2004. De Callirhoe narrationes amatoriae Chariton Aphrodisiensis. Edited by B. P. Reardon. Monacchi: K. G. Saur.

Fusillo, M. 1990. "Il testo nel testo: la citazione nel romanzo greco." In Materiali e discussioni per l' analisi dei testi classici, 25 (Studi sul romanzo antico): 27-48.

Hirschberger, M. 2001. "Epos und Tragödie in Charitons Kallirhoe: ein Beitrag zur Intertextualität des griechischen Romans." Würzburger Jahrbücher für die Altertumswissenschaft 25:157-86.

Homer. 1984. The Odyssey. Edited by G. P. Goold. Cambridge/Massachusetts: Harvard University Press.

Homer. 1960. The Iliad. Edited by A. T. Murray. Cambridge/Massachusetts: Harvard University Press.

${ }^{23}$ Ver p. ex. Quéreas E Calírroe 2.3.7, em que Dionísio cita uma passagem da Odisseia (17.485-7) para reforçar a ideia de que os deuses se misturam aos homens para vigiar seu comportamento.

${ }^{24}$ Gostaria de agradecer aos colegas Christian Werner e Isabella Tardin Cardoso por terem me propiciado o acesso a vários dos textos constantes da bibliografia. 
Laplace, M. 1980. "Les legends troyennes dans le roman de Chariton Cairéas et Callirhoé." Revue des Études Grecques 93:83-125.

Manuwald, G. 2000. "Zitate als Mittels der Erzählene: zur Darstellungstechnik Charitons in seinen Roman Challirhoe." Würzburger Jachbücher fur die Altertumwissenchaft 24:97-122.

Morales, M. S.; G. L. Marisal. 2003. “The relationship between Achilles and Patroclus according to Chariton of Afrodisias." The Classical Quarterly 53(1):292-5.

Morgan, J. 2008. "Intertextuality. 1. The Greek novel." In The Cambridge Companion to the Greek Novel, edited by Tim Whitmarsh, 218-27. Cambridge: Cambridge University Press.

Müller, C. W. 1976. "Cariton von Aphrodisias uns die Theorie des Romans in Antike." Antike \& Abenland 22:115-36.

Reardon, B. P. 2003. "Chariton." In The novel in the ancient world, edited by Gareth L. Schmeling, 309-35. Boston: Brill Academic Publishers.

Robiano, P. 2000. "La citation poétique dans le roman érotique grecque." Revue des études anciennes 102(3/4):509-29.

Tilg, S. 2010. Chariton of Aphrodisias and the invention of the Greek love novel. Oxford: Oxford University Press.

Whitmarsh, Tim. 2011. Narrative and identity in the ancient Greek novel. Cambridge: Cambridge University Press.

\section{*}

Titre. Une formule homérique et son emploi par Chariton : une étude de cas.

Résumé. On sait qu'Homère constitue la principale référence intertextuelle de Chariton. Malgré le nombre croissant d'études sur cette relation, il reste encore beaucoup à explorer. Le but de cette communication est d'examiner l'emploi d'une formule ho-

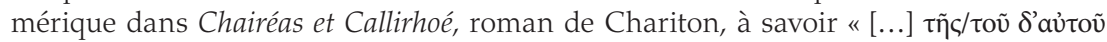

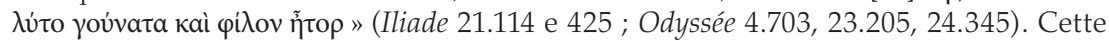
formule, appliquée à Callirhoé, à Chairéas et à Dionysios, se répète trois fois au long du roman (C\&C $1.1 .14,3.6 .3,4.5 .9)$. J'ai l'intention de vérifier si l'auteur fait une utilisation purement générique de la citation, ne retenant que son sens plus général, dans le seul but de prêter à son œuvre le prestige du poète archaïque, ou s'il y a une intention d'évoquer un contexte spécifique du poème cité, de manière à créer une expectative parmi ses lecteurs concernant le développement de l'œuvre. Il reste encore une troisième possibilité, celle que son utilisation soit liée à un autre but, à savoir celui de légitimer une caractéristique stylistique du propre auteur, celle de créer ses propres formules, à travers l'émulation du barde ancien.

Mots-clés. Intertextualité ; roman érotique grecque ; épopée ; Chariton ; Chairéas et Callirhoé ; Homère. 